\title{
Incisional hernia swine: Case report
}

\author{
Hérnia incisional em suínos: Relato de caso \\ Hernia incisional en porcinos: Reporte de caso
}

Received: 03/09/2021 | Reviewed: 03/16/2021 | Accept: 03/18/2021 | Published: 03/26/2021

\author{
Mirlam de Oliveira Sampaio Júnior \\ ORCID: https://orcid.org/0000-0003-4217-305X \\ Universidade Federal do Oeste da Bahia, Brazil \\ E-mail: mirlamoliveirasjr@gmail.com \\ Ana Karoline Rodrigues da Costa \\ ORCID: https://orcid.org/0000-0001-6671-8099 \\ Universidade Federal do Oeste da Bahia, Brazil \\ E-mail: karolrdac@gmail.com \\ Danilo Rocha de Melo \\ ORCID: https://orcid.org/0000-0003-4793-7338 \\ Universidade Federal do Oeste da Bahia, Brazil \\ E-mail: danilomelo.vet@gmail.com \\ Marcos Wilker da Conceição Santos \\ ORCID: https://orcid.org/0000-0002-6357-1236 \\ Universidade Federal do Oeste da Bahia, Brazil \\ E-mail: vilker.mwcs@gmail.com \\ Jessica Fontes Veloso \\ ORCID: https://orcid.org/0000-0001-8183-0628 \\ Universidade Federal do Oeste da Bahia, Brazil \\ E-mail: jessica.veloso@ufob.edu.br \\ Larissa José Parazzi \\ ORCID: https://orcid.org/0000-0002-4093-7901 \\ Universidade Federal do Oeste da Bahia, Brazil \\ E-mail: larissa.parazzi@ufob.edu.br \\ Alexandra Soares Rodrigues \\ ORCID: https://orcid.org/0000-0001-6821-4142 \\ Universidade Federal do Oeste da Bahia, Brazil \\ E-mail: alexandra.rodrigues@ufob.edu.br \\ Vinicius de Jesus Moraes \\ ORCID: https://orcid.org/0000-0003-4245-9648 \\ Universidade Federal do Piauí, Brazil \\ E-mail: vini.moraes.vet@hotmail.com \\ Deusdete Conceição Gomes Júnior \\ ORCID: https://orcid.org/0000-0003-0928-0961 \\ Universidade Federal do Oeste da Bahia, Brazil \\ E-mail: deusdete.gomes@ufob.edu.br
}

\begin{abstract}
The occurrence of incisional hernias in pigs is poorly described, so the objective of the study is to report a case of incisional hernia in pig treated with polypropylene mesh. A 1 year old male, mixed breed pig weighing $22 \mathrm{~kg}$ was treated at the HVU-UFOB. During the anamnesis, the owner reported that the animal had swelling in the abdominal region, having a suggestive diagnosis of umbilical hernia, confirmed by ultrasound. In view of the findings, it was decided to perform herniorrhaphy with direct suture. Ten days after surgery, adequate healing of the surgical wound was verified with the absence of a hernial ring. Fifty-one after surgery, the animal returned with an increase in abdominal volume at the surgery site. On physical examination, the presence of a $12 \mathrm{~cm}$ ring and reducible intestinal loops in the hernial sac were identified. After a new ultrasound examination, the diagnosis of incisional hernia was defined. A new herniorrhaphy with polypropylene mesh was chosen. After 10 days, the wound healing was verified. Incisional hernias in pigs are generally related to the animal's age, sex, breed and species, as well as flaws in the surgical technique. Biological or synthetic materials are used for the correction, in order to reinforce safety in the incision line. One year after herniorrhaphy, there was no recurrence, which shows a satisfactory result with the use of the polypropylene mesh.
\end{abstract}

Keywords: Pig; Herniorrhaphy; Polypropylene mesh.

\section{Resumo}

A ocorrência de hérnias incisionais em suínos é pouco descrita, portanto o objetivo do estudo é relatar um caso de hérnia incisional em suíno tratado com tela de polipropileno. Um suíno macho, sem raça definida, com 1 ano de idade, 
pesando $22 \mathrm{~kg}$ foi atendido no HVU-UFOB. Durante a anamnese, o proprietário relatou que o animal apresentava inchaço na região abdominal, tendo diagnóstico sugestivo de hérnia umbilical, confirmado por ultrassonografia. Diante dos achados, optou-se por realizar a herniorrafia com sutura direta. Dez dias após a cirurgia, foi verificada adequada cicatrização da ferida operatória com ausência de anel herniário. Cinquenta e um dia após a cirurgia, o animal retornou com aumento de volume abdominal no local da cirurgia. No exame físico, identificou-se a presença de anel de $12 \mathrm{~cm}$ e alças intestinais redutíveis no saco herniário. Após novo exame ultrassonográfico, foi definido o diagnóstico de hérnia incisional. Optou-se por nova herniorrafia com tela de polipropileno. Após 10 dias, foi verificada a cicatrização da ferida operatória. Hérnias incisionais em suínos, geralmente estão relacionadas à idade do animal, sexo, raça e espécie, bem como falhas na técnica cirúrgica. Materiais biológicos ou sintéticos são usados para a correção, com o objetivo de reforçar a segurança na linha de incisão. Após um ano da herniorrafia, não houve recidiva, o que mostra um resultado satisfatório com o uso da tela de polipropileno.

Palavras-chave: Porco; Herniorrafia; Tela de polipropileno.

\section{Resumen}

La aparición de hernias incisionales en cerdos está pobremente descrita, por lo que el objetivo del estudio es reportar un caso de hernia incisional en cerdo tratado con malla de polipropileno. En el HVU-UFOB se trató un cerdo macho de raza mixta de 1 año que pesaba $22 \mathrm{~kg}$. Durante la anamnesis, el dueño informó que el animal presentaba hinchazón en la región abdominal, teniendo un diagnóstico sugestivo de hernia umbilical, confirmado por ecografía. Ante los hallazgos se decidió realizar herniorrafia con sutura directa. Diez días después de la cirugía se verificó una adecuada cicatrización de la herida quirúrgica con ausencia de anillo herniario. Cincuenta y uno después de la cirugía, el animal regresó con un aumento del volumen abdominal en el sítio de la cirugía. Al examen físico se identificó la presencia de un anillo de $12 \mathrm{~cm}$ y asas intestinales reducibles en el saco herniario. Tras una nueva ecografía se definió el diagnóstico de hernia incisional. Se eligió una nueva herniorrafia con malla de polipropileno. Después de 10 días, se verificó la cicatrización de la herida. Las hernias incisionales en cerdos suelen estar relacionadas con la edad, sexo, raza y especie del animal, así como con defectos en la técnica quirúrgica. Para la corrección se utilizan materiales biológicos os sintéticos, con el fin de reforzar la seguridad en la línea de incisión. Un año después de la herniorrafia, no hubo recidiva, lo que muestra un resultado satisfactorio con el uso de la malla de polipropileno.

Palabras clave: Cerdo; Herniorrafia; Malla de polipropileno.

\section{Introduction}

Hernias can be congenital or acquired and consist of defects in anatomical structures that allow abnormal tissue or organ protrusion. Abdominal hernias are characterized by the opening of the musculature of the abdominal wall, classified as ventral or inguinal depending on its location, and reducible or irreducible according to the possibility of returning its content to the original cavity (Nunes, et al., 2019).

Incisional hernias are characterized by defects in the abdominal wall in areas of previous surgical incisions (Markovic, et al., 2016). Incisional hernia is the most common complication of laparoscopic surgeries in humans and some factors such as advanced age, use of corticosteroids, previous surgeries and surgical wound infections are related to the increase in their incidence (Nho, et al., 2012). The risk factors involved in the onset of incisional hernia can be divided into related to patient such as collagen deficiency, factors of the surgical technique such as the incision site, and postoperative factors such as surgical site infection, which is the most related (Sanders \& Kingsnorth, 2012).

In pigs' umbilical hernias are frequent defects, can occur due to infections, changes in the development of the region's musculature, and may be related to genetic inheritance or incorrect management of the umbilical cord, with complication of intestinal incarceration (Sobestiansky, et al., 2012; Barcellos, et al., 2017). In rarer cases it can be caused due to persistent uracus (Borrás, 1983) since the junction of the umbilical vein, two arteries, yolk sac and uracus form the umbilical cord of the swines (Souza, et al., 2012).

The repair of abdominal hernias is performed through direct suture of the tissue edges or by the application of synthetic or biological surgical meshes. In humans, when compared to the repair performed only with direct suture, which is indicated in cases of defects up to three centimeters, the use of meshes considerably reduces recurrence (Sanders \& Kingsnorth, 2012). In humans, the use of meshes is associated with higher rates of infection, chronic pain, and adherence (Rastegarpour, et al., 2016), which presupposes that there is no standard technique for correcting incisional hernias, and 
patients should be evaluated individually (Claus, et al., 2019). The occurrence of incisional hernias in pigs is poorly described, probably due to the lack of routine in performing abdominal surgeries in this type of production.

The aim of the study is to report a case of incisional hernia in swine treated at the Veterinary Hospital of the Federal University of Western Bahia (HVU-UFOB).

\section{Methodology}

The present study was carried out using a qualitative methodology (Pereira, et al., 2018), describing in detail a case of incisional hernia in a pig treated with polypropylene mesh. For this, clinical, anesthetic, and surgical data from the swine patient were used, showing the evolution of the case and the treatment employed, and looking for correlations for the development of the incisional hernia.

\section{Case Report}

A swine was treated at the HVU-UFOB, male, without breed defined, 1 year old, weighing $22 \mathrm{~kg}$. During the anamnesis, the owner reported that the animal was swelling in the abdominal region (Figure 1). The physiological parameters were within the normal range for the species. In the specific examination, there was an increase in volume in the abdomen region and during palpation; it was possible to identify structures such as the ring (about $30 \mathrm{~cm}$ ), sac and hernial content.

Figure 1. Swine swelling in the abdominal region before surgery.

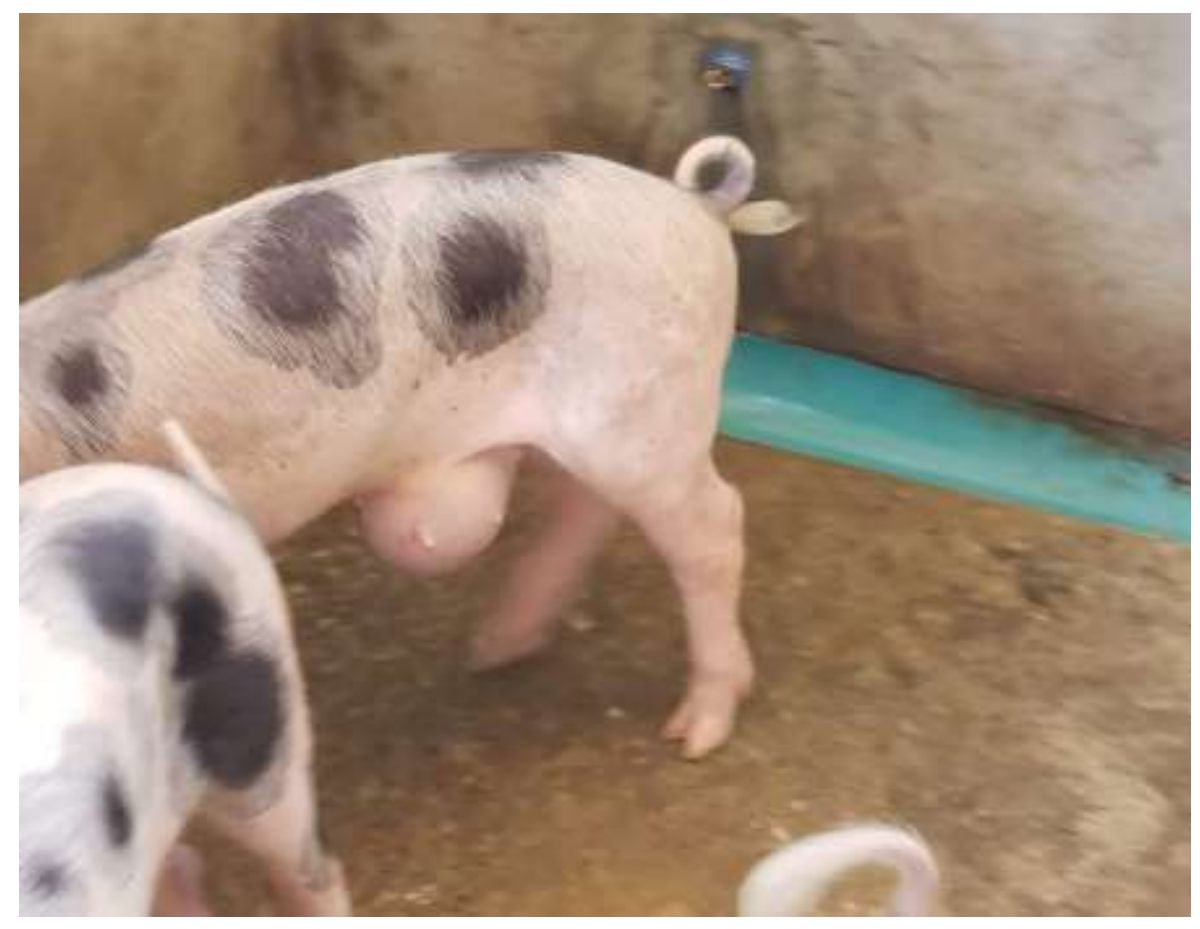

Source: Personal archive.

It was identified as reducible content, intestinal loops, and sensitivity to palpation was noted. Additionally, it was identified in the subcutaneous tissue, in the vicinity of the hernial ring, a spherical mass with about $6 \mathrm{~cm}$ in diameter of firm consistency in the region of the umbilical scar. The suggestive diagnosis was umbilical hernia, confirmed by ultrasound examination, which confirmed the presence of the mass heterogeneous being predominantly hypoechogenic with multiple 
hyperogenic points dispersed in the structure, but did not contribute to its diagnosis. In view of the findings, it was decided to perform classical herniorrhaphy and explore the site of insertion of the mass (Figure 2).

Figure 2. Abdominal exploration by the site of insertion of the mass was observed hernial ring.

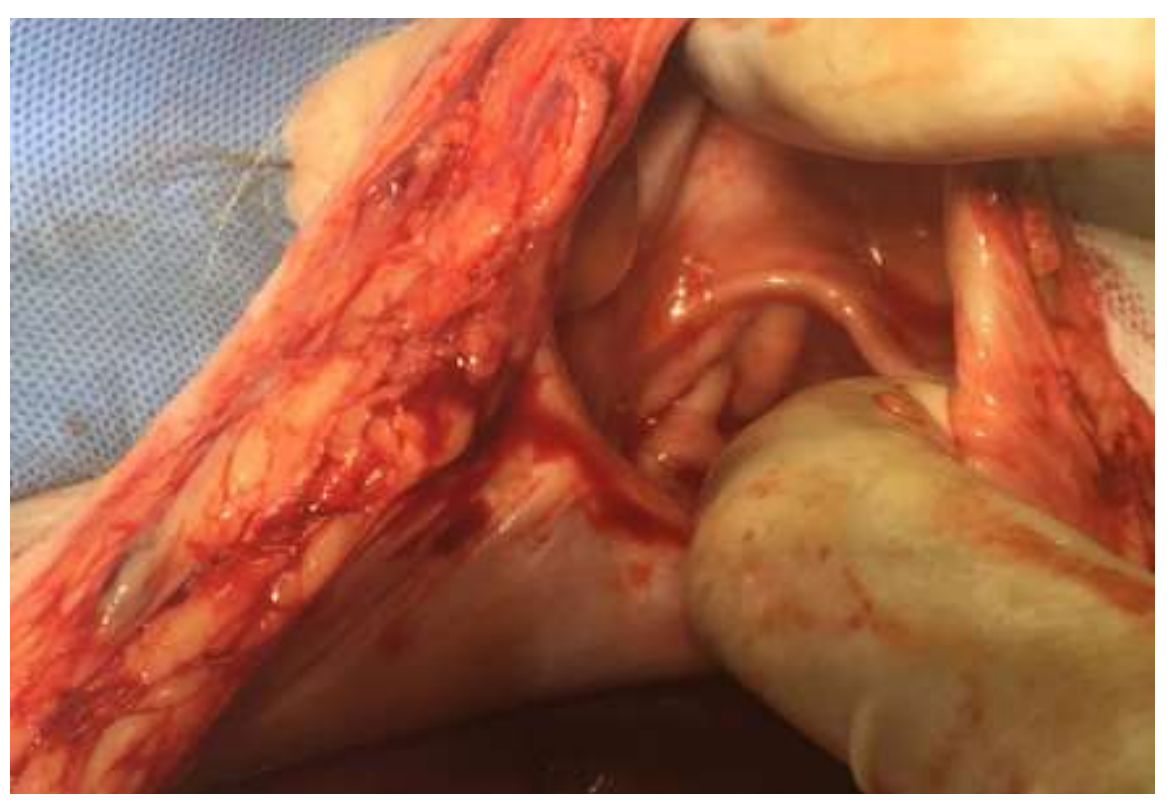

Source: Personal archives.

The animal was subjected to dissociative anesthesia with ketamine (Ketamin $®, 22 \mathrm{mg} / \mathrm{kg}$, i.v) and midazolam (Dormire ${ }^{\circledR}, 0.3 \mathrm{mg} / \mathrm{kg}$, i.v) intravenously, and local infiltrative anesthesia in the incision line with lidocaine in a vasoconstrictor (Lidovet ${ }^{\circledR} 2 \%, 10 \mathrm{ml}$ ). Enrofloxacin (Baytril ${ }^{\circledR}, 3 \mathrm{mg} / \mathrm{kg}$, i.v) and ketoprofen (Ketoflex ${ }^{\circledR}, 1.1 \mathrm{mg} / \mathrm{kg}$, i.v) were administered intravenously.

This was followed by celiotomy with a section of the skin and divulsion of the subcutaneous tissue where it was possible to identify the hernia ring measuring $31 \mathrm{~cm}$, the hernia sac, and its contents, in addition to the presence of an abscess of $6.2 \mathrm{~cm}$ in diameter. A routine procedure was performed, initiated by opening the hernia sac, section of excess portion, debridement of the edges and synthesis with nylon 1 (Procare®) with Mayo's double-breasted suture pattern. This was followed by careful dissection of the abscess, which eventually ruptured, but its content was restricted to the field compresses that surrounded it. A fistulous path identified between the abscess and the umbilical scar was also removed. The surgical area was copiously washed with $0.9 \%$ saline solution, followed by the reduction of dead space with nylon 2.0 with intradermal pattern and dermorraphy with nylon 1 with Wolf pattern.

Metronidazole (Flagyl®, 25mg/kg, i.v) was given intravenously, tramadol (Tramadon®, 2mg/kg, i.d) intradermally and enrofloxacin (Baytril®, 3mg/kg, i.m, BID, for 5 days) was prescribed, and ketoprofen (Ketoflex®, 1.1mg/kg, i.m, SID, for 2 days), both intramuscularly.

Ten days after surgery, adequate healing of the surgical wound was verified, and the stitches were removed. There was an absence of a hernial ring, pain, or discomfort; however, there was intense fibrosis in the muscles. It was observed that the animal had slight muscular atrophy and was unable to support the right posterior limb, being reported by the owner that this fact occurred after the last application of the antibiotic intramuscularly. In the case of a possible injury to the sciatic nerve, hydrocortisone (Gliocort ${ }^{\circledR}, 50 \mathrm{mg} / \mathrm{kg}$, i.m, SID, for 2 days) was given daily once for two days, intramuscularly, and later was informed by the owner that the animal returned to stand on its member on the same day as the first injection. 
Fifty-one days after surgery, the animal returned with an increase in abdominal size at the surgical site. The patient had no clinical changes and weighed $37 \mathrm{~kg}$. On physical examination, the presence of a $12 \mathrm{~cm}$ ring was identified, intestinal loops were reducible in the hernial sac, and there was no pain or discomfort. After a new ultrasound examination, the diagnosis of incisional hernia was defined.

We decided for a new herniorrhaphy using a polypropylene mesh to reinforce the muscle wall. The same anesthetic protocol as the previous procedure was performed. During dissection of the hernial ring, intense adherence of the omentum to the hernial sac was identified, which was carefully dissected. After tissue debridement, the musculature was approached with nylon 1 in an "X" pattern, and the polypropylene mesh was subsequently applied, which was fixed using a simple stitch interrupted with nylon 0 . The subcutaneous tissue was approached with an intradermal pattern and dermorraphy with Wolf pattern, both with 2.0 nylon thread.

After 10 days, adequate healing of the surgical wound was verified and the stitches were removed, with the absence of a hernial ring, pain, or discomfort (Figure 3). The animal remained in the farm until reaching ideal weight for slaughter, hernia recurrence was not identified.

Figure 3. Swine 10 days after surgery, without swelling in the abdominal region. Adequate healing of the surgical wound and absence of the hernial ring was observed.

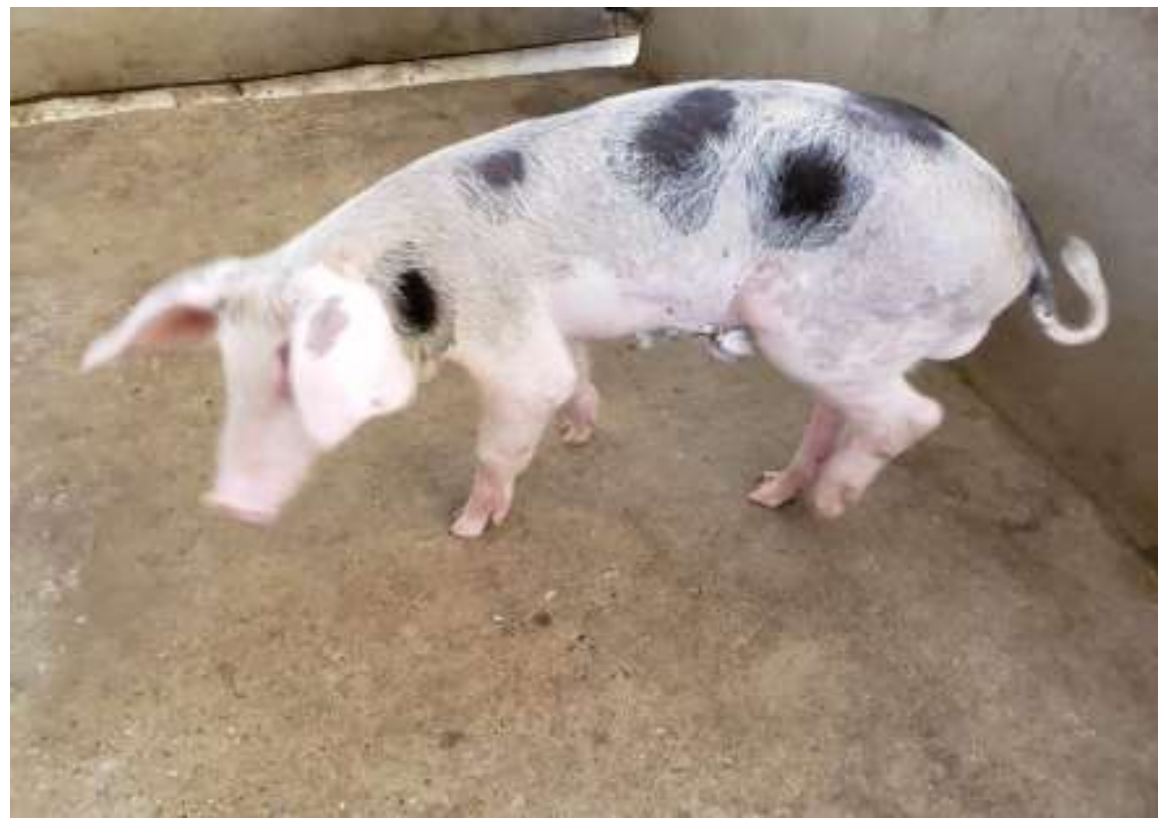

Source: Personal archives.

\section{Discussion}

In the literature, the occurrence of incisional hernias in pigs is little reported, probably due to the lack of routine in performing abdominal surgeries in this species. In general, in large animals, an incidence of more than $16 \%$ is noted, while in dogs and cats the prevalence is lower, reaching around 6.5\%, not being routine in these species. In humans, the incidence of incisional hernias is 4 to $10 \%$, being a common complication of laparoscopic surgeries (Dietz, et al., 2018).

The increase in abdominal volume caused by hernia must be differentiated from abscesses, soft tissue tumors, lymphadenomegaly, hydrocele and osteitis (Simons et al., 2009, Claus et al., 2019) and the diagnosis of incisional hernia can be obtained through association of information about previous surgical procedure together with clinical examination where the 
composition of a true hernia is identified (Faria, et al., 2016). However, the use of ultrasound examination is justified to confirm and define the surgical approach to be performed (Claus, et al., 2019).

Because of the diagnosis and aiming at a lower cost in the procedure, it was decided to perform classical herniorrhaphy, using a suture pattern to overlap the abdominal muscle walls. Hernia correction can be performed through direct approximation of tissue borders (Read \& Bellenger, 2002); however, other authors suggest that direct suturing in humans should be performed only in cases where the hernias are less than three centimeters in order to prevent recurrences (Sanders \& Kingsnorth, 2012).

The existence of a restricted abscess with a fistulous path towards the hernia observed at the time of the first surgical procedure suggests a primary inflammatory reaction to the hernia. In piglets, it is common to have fights or aggressive reactions due to issues of inadequate handling or stress. The hernia extension in the reported pig may have been due to management failures, such as umbilical bite, development of an inflammatory reaction at the site and infection, which prevented the proper apposition of the muscle borders in their early life.

Fifty-one days after classical herniorrhaphy, the animal was diagnosed with incisional hernia. The occurrence of incisional hernia is generally related to the age of the animal, sex, breed and species (Faria, et al., 2016), as well as flaws in the surgical technique, mainly related to suturing, concomitant diseases that cause increased intra-abdominal pressure and the animal's behavior, especially when there are too many physical efforts that cause an increase in intra-abdominal pressure on the incision line and favors the rupture of the suture (Schulz, et al., 2003). The recurrence in swine may have been due to the association of some factors such as the rupture of the abscess that contaminated the surgical site (Millikan, 2003), the use of corticosteroids in the postoperative period, which reduces the inflammatory process and consequently delays tissue healing (Rosen, et al., 2008; Gupta, et al., 1999) in addition to the animal's weight gain and quadrupedal position, which increases the tension in the incision line (Schulz, et al., 2003). In addition, the suture pattern used, even being indicated for the correction of hernias in domestic animals, may not have prevented recurrences due to the large extension of the initial hernia ring of 31 centimeters.

The identification of adhesions of the omentum to the muscle wall during the correction of the incisional hernia in the second surgical procedure reinforces the hypothesis of infection at the surgical site (Biondo-Simões, et al., 2018) since this organ protects the abdominal structures against the spread of infection, promoting adherence, vascularization with consequent contribution of defense cells (Nicola, 2019).

For the correction of incisional hernias, biological or synthetic materials are used to reinforce safety in the incision line. Such materials were necessary to correct the hernia of the pig since the direct closure was not effective. Canine diaphragmatic phrenic center has been reported in order to achieve these reconstructive objectives (Azevedo, et al., 2018). However, in the face of contamination (fistula/adherence), the use of synthetic material is even more justified. The polypropylene mesh is a synthetic material that has ideal characteristics, such as being inert and presenting macropores that facilitate the proliferation of fibroblasts allowing excellent surgical adhesion (Gonzalez, et al., 2004), lower rates of complications and less painful reaction in the post-operative (Gentile, et al. 2016). Its use in the repair of incisional hernia in a cow proved to be effective in reducing tension in the incision line and reducing the recurrence rate (Raghunath, et al., 2017).

No recurrence was observed after one year of herniorrhaphy, which shows a satisfactory result in the use of polypropylene mesh.

\section{Final Considerations}

Incisional hernia in swine is a relevant topic, but it is rarely reported in the literature. In this case, satisfactory result was observed using the polypropylene mesh compared to the direct hernia closure, demonstrating fewer complications and no 
recurrence. It is important to emphasize the necessity of the veterinarian to have knowledge of surgical techniques using synthetic material in the treatment of hernias and the types of synthetic materials used. Finally, in future studies, it is suggested that the etiopathogenesis of incisional hernias be more exploited in the swine species, as well as the influence of surgical technique, the choice of biological or synthetic materials for suture and postoperative pharmacotherapy in decreasing or increasing the incidence of incisional hernia appearance.

\section{References}

Azevedo, R. A., \& Stopiglia, A. J (2018). Principais materiais biológicos e sintéticos utilizados em cirurgias para reconstrução de parede abdominal na Medicina Veterinária: revisão de literatura. Revista de Educação Continuada em Medicina Veterinária e Zootecnia do CRMV-SP, 16(2) 42-46.

Barcellos, D. E., Fernando, P. B., Ivo, W., Mari, L. B., Mellagi, A. P. G., \& Algum, R. R (2017). Possíveis erros na avaliação de hérnias umbilicais em frigoríficos suínos. In: D.E., Barcelos, Avanços em sanidade, produção e reprodução de suínos (2a ed.), 128-134.

Biondo-Simões, M. L. P., Pessini, V. C. A., Porto, P. H. C., \& Robes, R. R. (2018). Aderências em telas de polipropileno versus telas Sepramesh®: estudo experimental em ratos. Revista do Colégio Brasileiro de Cirurgiões, 45(6), 1-11.

Borrás, M (1983). 3 Cases of persistent urachus with umbilical abscess in Wistar rats. Laboratory Animal, 17, 55-58.

Claus, C. M. P., Oliveira, F. M., Furtado, M. L., Azevedo, M. A., Roll, S., Soares, G., Nacul, M. P., Rosa, A. L. M., Melo, R. M., Beitler, J. C., Cavalieri, M. B., Morrell, A. C., \& Cavazzola, L. T (2019). Orientações da Sociedade Brasileira de Hérnia (SBH) para o manejo das hérnias inguinocrurais em adultos. Revista do Colégio Brasileiro de Cirurgiões, 46(4).

Dietz, Ulrich A. et al (2018). The treatment of incisional hernia. Deutsches Ärzteblatt International, $115(3), 31$.

Faria, B. G. O, Oriá, A. P., Martins Filho, E. F. M., Conceição, D. G., Neto, F. A. D., Quessada A. M, Carneiro, R. S. \& Neto, J. M. C (2016). Pathophysiology and treatment of iatrogenic abdominal hernia in feline - a Case report. Brazilian Journal of Veterinary Medicine, $38(1.1)$.

Gentile, J. K. A. Neto, A. R., Teixeira, T. R., Birindelli, J. P. A.; \& Bassil, M. A (2016). Estudo das telas cirúrgicas de polipropileno/poliglecaprone-25 e polipropileno monofilamentar no reparo de hérnias inguinais. Revista Sociedade Brasileira Clínica Médica ,14(4), 195-8.

Gonzalez, R., Rodeheaver, G. T., Moody, D. L., Foresman, P. A., \& Ramshaw, B.J (2004). Resistance to adhesion formation: A comparative study of treated and untreated mesh products placed in the abdominal cavity. Hernia 8, 213-219.

Gupta, A., Jain, G. K., \& Raghubir, R. A (1999). Time course study for the development of an immunocompromised wound model, using hydrocortisone. Journal Pharmacol Toxicology Methods, 41(4), 183-7.

Markovic, A, Barreira, M. A, \& Goes, A. C. A. M (2016) Hérnia incisional: proposta de um fluxograma que oriente o tratamento incisional hérnia: proposal for a flow chart to guide treatment. In: Journal of the Biologia Health Science Institute, 4(4), 257-264.

Millikan, K. M (2003). Incisional hernia repair. The surgical clinics of North America, 83 (5), 1223-1234.

Nho, R. L. H., Mege, D., Quaissi, M., Sielezneff, I., \& Sastre, B. N (2012). Incidence and prevention of ventral incisional hernia. Journal of Visceral Surgery, 149(5), 3-14.

Nicola, V (2019). Omentum is a powerful biological source in regenerative surgery. Regenerative Therapy.11, 182-191.

Nunes, C. P, Rocha, I. C, Miranda, D. C, \& Carvalho, C.C (2019) "Atualização sobre malha cirúrgica nas hérnias incisionais”. Revista Caderno de Medicina Vol 2, (2), 6 .

Pereira, A. S, Shitsuka, D. M., Parreira, F. J., \& Shitsuka, R. (2018). Metodologia da pesquisa científica. UFSM. https://repositorio.ufsm.br/bitstrea $\mathrm{m} /$ handle/1/1 5824/Lic_Computacao_Metodologia-Pesquisa-Cientifica.pdf?sequence=1.

Raghunath, M., Sagar, P. V, \& Ravikumar, P. (2017). Hernioplasty using Polypropylene Mesh for Surgical Management of Ventral Hernia in a Crossbred cow. Intas Polivet, 18 (2).

Rastegarpour, A., Cheung, M., Vardhan, M., Ibrahim, M. M., \& Butler, C. E (2016). Surgical mesh for ventral incisional hernia repairs: Understanding mesh design, Plastic surgery (Oakville, Ont.), 24(1), 41-50.

Read, R. A. \& Bellenger, C. R. (2002). Hérnias. In: D. Slatter, Textbook of small animal surgery. Philadelphia: Saunders (3a ed, Cap.31, pp. 529-533).

Rosen, D. J., Patel, M. K., Freeman, K., \& Weiss, P. R (2008). A primary protocol for the management of ear keloids: results of excision combined with intraoperative and postoperative steroid injections. Erratum in: Plastic and Reconstructive Surgery, 121(1), 347.

Sanders, D. L., \& Kingsnorth, A. N. (2012). The modern management of incisional hernias. British Medical Journal, $344(1), 2843$.

Schulz, M. S, Uherek, F. P., \& Mejías, P.G (2003). Hernia incisional "Articulo de Actualizacion”. Cuad. Cir. Instituto de Cirugía, Facultad de Medicina, Universidad Austral de Chile, 17, 103-111. 
Research, Society and Development, v. 10, n. 3, e55310313727, 2021

(CC BY 4.0) | ISSN 2525-3409 | DOI: http://dx.doi.org/10.33448/rsd-v10i3.13727

Simons, M. P., Aufenacker, T., Bay-Nielsen, M., Bouillot, J. L., Campanelli, G., Conze, J., de Lange, D., Fortelny, R., Heikkinen, T., Kingsnorth, A., Kukleta, J., Morales-Conde, S., Nordin, P., Schumpelick, V., Smedberg, S., Smietanski, M., Weber, G., \& Miserez, M. (2009). European Hernia Society guidelines on the treatment of inguinal hernia in adult patients. Hernia: the journal of hernias and abdominal wall surgery, 13(4), 343-403.

Sobestiansky, J, Carvalho, L. F. O. S., \& Barcellos, D. (2012). Malformações. In: J. Sobestiansky \& D. Barcellos (Eds), Doenças dos Suínos (2ª ed. pp. 627645). Goiânia: Cânone Editorial.

Souza, M. A., Sobestiansky, J., \& Barcellos, D (2012). Onfalites em leitões lactentes. In: J. Sobestiansky \& D. Barcellos (Eds), Doenças dos Suínos (2a ed.), Cânone Editorial. 